Tersedia online di: http://ejournal-balitbang.kkp.go.id/index.php/bawal
e-mail:bawal.puslitbangkan@ gmail.com
BAWAL WIDYA RISET PERIKANAN TANGKAP
Volume 9 Nomor 2 Agustus 2017
p-ISSN: 1907-8226
e-ISSN: 2502-6410
BAWAL
Nomor Akreditasi: 620/AU2/P2MI-LIPI/03/2015

\title{
STRUKTUR UKURAN DAN BEBERAPA PARAMETER POPULASI IKAN CAKALANG (Katsuwonus pelamis Linnaeus, 1758) DI SAMUDERA PASIFIK UTARA PAPUA
}

\section{SIZE STRUCTURE AND SOME POPULATION PARAMETERS OF SKIPJACK TUNA (Katsuwonus pelamis Linnaeus, 1758) IN THE PASIFIC OCEAN NORTH OF PAPUA}

\author{
Thomas Hidayat, Tegoeh Noegroho dan Karsono Wagiyo \\ Balai Riset Perikanan Laut, Kompleks Raiser, Jl. Raya Bogor KM. 47 Cibinong, Bogor \\ Teregistrasi I tanggal: 03 Februari 2017; Diterima setelah perbaikan tanggal: 07 Nopember 2017; \\ Disetujui terbit tanggal: 15 Nopember 2017
}

\begin{abstract}
ABSTRAK
Ikan cakalang (Katsuwonus pelamis Linnaeus, 1758) merupakan salah satu sumberdaya ikan pelagis besar yang mempunyai nilai ekonomis penting. Informasi mengenai struktur ukuran dan beberapa parameter populasinya masih sangat terbatas khususnya di perairan Indonesia timur. Penelitian ini dilakukan di Morotai, Biak dan Jayapura dari Januari sampai Desember 2013. Tujuan penelitian ini adalah untuk menganalisis ukuran ikan yang tertangkap dan menganalisis parameter populasi meliputi laju pertumbuhan, mortalitas dan tingkat eksploitasi. Estimasi parameter pertumbuhan, mortalitas dan laju eksploitasi dihitung menggunakan program FiSAT (FAOICLARM Stock Assessement Tools). Ukuran ikan cakalang hasil tangkapan pancing tonda dan pancing ulur berkisar antara 15 - $94 \mathrm{cmFL}$ (Fork Length), dengan modus antara 40-45 cmFL. Ukuran pertama kali tertangkap sebesar 40,1 cmFL dan kebanyakan adalah ukuran ikan yang sedang memijah. Hasil analisis menggunakan FiSAT II diperoleh laju pertumbuhan (K) sebesar 0,41/tahun, panjang asimptotik (L $\infty$ ) 101,85 cmFL. Laju kematian alami (M) 0,6 / tahun, laju kematian karena penangkapan (F) 0,62 /tahun dan laju mortalitas total (Z) 1,22 /tahun. Tingkat eksploitasi ikan cakalang hampir fully exploited $(\mathrm{E}=0,46)$. Disarankan tidak perlu ada penambahan upaya penangkapan atau status quo untuk menjaga agar sumberdaya ikan cakalang tetap terjaga kelestariannya.
\end{abstract}

Kata Kunci: Cakalang; stuktur ukuran; parameter populasi; Samudera Pasifik utara Papua

\section{ABSTRACT}

Skipjack tuna (Katsuwonus pelamis Linnaeus, 1758) is one of the large pelagic fish resources which have high economic value. Information on the size structure and population parameters is still limited especially in the waters of eastern Indonesia. The Research was conducted from January to December 2013 at Morotai, Biak and Jayapura. The aim of this study was to analyze the size of the fish caught and some of population parameters such as the growth rate, mortality rates, and exploitation rate. Estimated of growth parameters, mortality and exploitation rate using the program FiSAT (FAO-ICLARM Stock Assessement Tools). The size of skipjack tuna caught by troll line and handline in between 15-94 cmFL, with a mode of 40-45 cmFL. The Length at first capture was $40.1 \mathrm{cmFL}$, most of them had condition of spawning. By using program FiSAT II analysis resulted that growth rate $(K)$ of skipjack tuna was $0.41 /$ year, with length asimptotik $(L \infty)$ reaches $101.85 \mathrm{cmFL}$. The natural mortality rate $(M)$ was $0.6 /$ year. The fishing mortality rate $(F)$ was $0.62 /$ year and total mortality rate $(Z)$ was $1.22 /$ year. The exploitation rate of skipjack tuna was nearly fully exploited $(E=0.46)$. It was recommended the exploitation rate of this fish should be no additional effort (status quo) to keep sustainability of the skipjack tuna resource.

Keywords: Skipjack tuna; size structure; population parameter; Pacific Ocean north of Papua 


\section{PENDAHULUAN}

Sumberdaya ikan pelagis besar di Wilayah Pengelolaan Perikanan NRI 717 (meliputi Teluk Cendrawasih dan Samudera Pasifik utara Papua) merupakan salah satu komoditas penting perikanan Indonesia yang sudah dieksploitasi sejak lama. Ikan pelagis besar meliputi jenisjenis tuna terdiri dari tuna madidihang (Thunnus albacares), cakalang (Katsuwonus pelamis), tuna mata besar (Thunnus obesus), albakora (Thunnus allalunga). Jenis ikan tuna neritik antara lain adalah tongkol abu-abu (Thunnus tonggol), tongkol komo (Euthynnus affinis), tongkol krai (Auxis thazard), tongkol lisong (Auxis rochei), tenggiri (Scomberomorus commerson) dan tenggiri papan (Scomberomorus guttatus).

Pada tahun 2010 hasil tangkapan tertinggi di Samudera Pasifik bagian tengah dan barat adalah cakalang yaitu sebesar 1.706 .166 ton atau sekitar $71 \%$ dari total tangkapan, sedangkan hasil tangkapan madidihang tahun 2010 mencapai 470.161 ton atau sekitar $19 \%$, sisanya merupakan jenis tuna lainnya. Selama tahun 2010, alat tangkap purse seine menyumbang sekitar 1.820 .844 ton (75\% dari total tangkapan ikan), huhate diperkirakan 171.604 ton (7\%), rawai tuna diperkirakan 239.853 ton (10\%), dan sisanya (7\%) dari pancing tonda dan alat tangkap tradisional lainnya terutama di Indonesia timur dan Filipina (Siriraksophon, 2011).

Selain ikan tuna, perairan ini juga merupakan daerah penangkapan potensial untuk ikan cakalang. Pada tahun 2014 produksi ikan cakalang sebesar 10.323 ton atau $59 \%$ dari total produksi ikan pelagis besar di wilayah ini (Anonimus, 2014). Jenis-jenis alat tangkap yang digunakan menangkap tuna dan cakalang antara lain purse seine, huhate, pancing ulur dan pancing tonda. Perikanan pancing tonda dan pancing ulur merupakan perikanan skala kecil (small scale fisheries) yang dominan di wilayah Papua dan Morotai (Maluku Utara).

Tujuan dari penelitian ini adalah untuk mendapatkan informasi terkait struktur ukuran dan beberapa parameter populasi seperti laju pertumbuhan, tingkat kematian, tingkat eksploitasi, dan ukuran pertama kali tertangkap ikan cakalang (Katsuwonus pelamis). Dari hasil penelitian ini diharapkan dapat diketahui status pemanfaatan ikan cakalang Samudera Pasifik bagian barat dan dapat memberikan masukan untuk pengelolaan sumberdaya ikan tersebut secara berkelanjutan.

\section{BAHANDANMETODE Pengumpulan Data}

Pengumpulan data dilakukan mulai Januari sampai Desember 2013.Data ukuran panjang cagak (Fork Length/ FL) ikan cakalang (Katsuwonus pelamis) dikumpulkan setiap bulan dari hasil tangkapan nelayan pancing ulur (hand line) dan pancing tonda (troll line) yang beroperasi di sekitar rumpon dan mendaratkan hasilnya di Morotai, Biak dan Jayapura. Selanjutnya data panjang ini dikelompokkan dalam kelas panjang bulanan. Pengumpulan data dilakukan dengan bantuan enumerator yang ditunjuk. Lokasi penelitian ditunjukan pada Gambar 1.

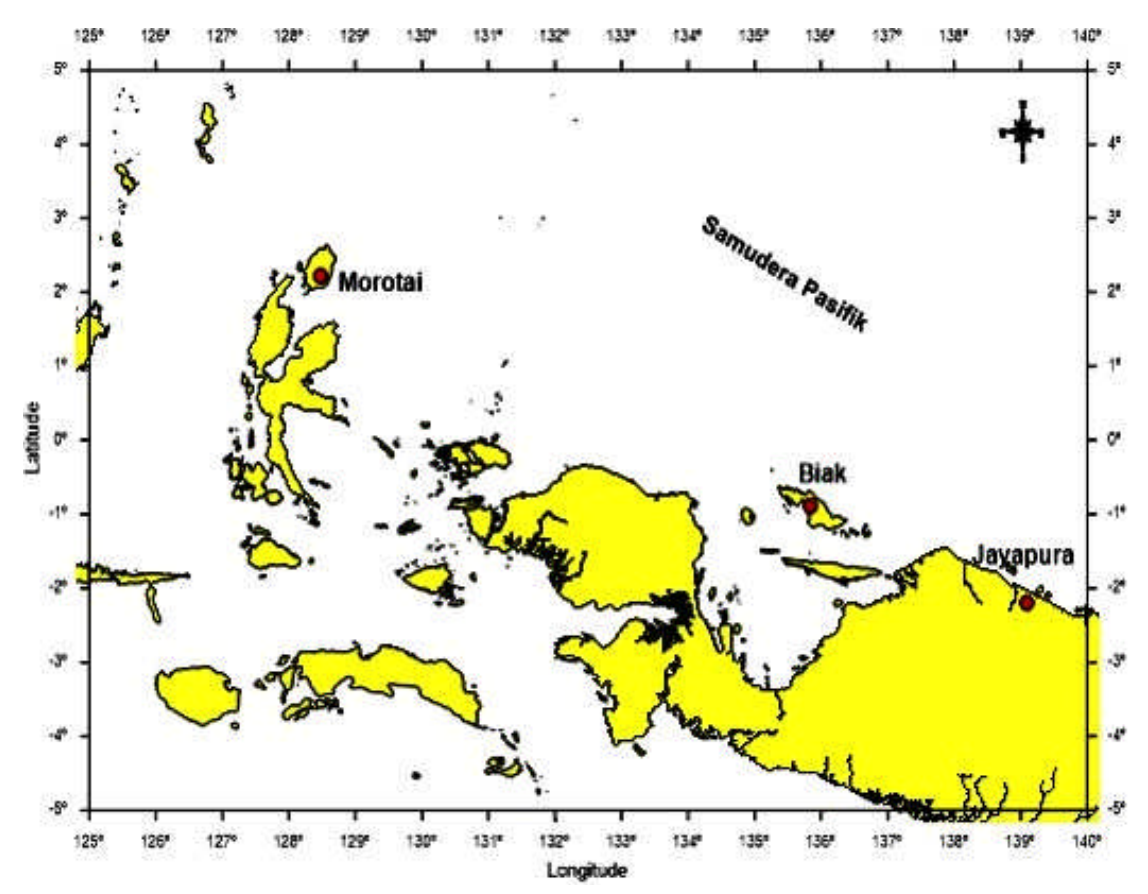

Gambar 1. Lokasi Pengambilan contoh cakalang di Samudera Pasifik utara Papua.

Figure 1. Sampling site of skipjack tuna in the Pacific Ocean north off Papua. 


\section{Analisis Data}

Ukuran ikan pertama kali tertangkap atau Length at first capture (Lc) merupakan $50 \%$ fraksi tertahan (ikan yang tertangkap) dari alat tangkap. Nilai Lc diperoleh dari data sebaran panjang yang dihitung dengan rumus (Sparre \& Venema 1999):

SLest $=1 /\left(1+\exp \left(\mathrm{S}_{1}-\mathrm{S}_{2} * \mathrm{~L}\right)\right)$

$\mathrm{Lc}=\mathrm{S}_{1} / \mathrm{S}_{2}$

dimana:

SLest : kurva logistic

$\mathrm{S}_{1}$ dan $\mathrm{S}_{2}$ : konstanta

Beberapa parameter populasi dianalisis menggunakan program FiSAT (FAO-ICLARM Stock Assessement Tools) II (Gayanilo et al., 1996). Panjang asimtotik dan nilai konstanta pertumbuhan diduga dengan menggunakan Program ELEFAN (Electronic Length Frequency Analysis) I yang dikembangkan oleh Pauly \& David (1981) dan Gayanilo et al., (1996). ELEFAN I adalah suatu analisis gerak maju sejumlah modus, yaitu menghubungkan modus ke modus dari length frekuensi bulanan dalam suatu runtun waktu sehingga membentuk suatu kurva. Pertumbuhan ikan dihitung dengan menggunakan rumus pertumbuhan Von Bertalanffy (Sparre \& Venema, 1999) sebagai berikut:

$\mathrm{Lt}=\mathrm{L} \infty\left(1-\mathrm{e}^{-\mathrm{K}(\mathrm{t}-\mathrm{t})}\right)$

\section{Dimana:}

$\mathrm{Lt}=$ panjang pada umur ke-t

$\mathrm{L}_{\infty}=$ panjang asimtotik

$\mathrm{K}=$ laju pertumbuhan

$\mathrm{t}_{0}=$ umur teoritis saat ikan berukuran panjang nol

Nilai dugaan umur teoritis pada saat panjang ikan sama dengan nol $\left(\mathrm{t}_{0}\right)$ ikan kurisi diperoleh dengan menggunakan rumus (Pauly, 1980) yaitu:

$\log \left(-t_{0}\right)=-0.3922-0.2752 \log -1.038 \log K$

Laju kematian alami (M) diduga dengan menggunakan hubungan empiris dari Pauly (1980) yaitu:

$\log (\mathrm{M})=\quad-0,0066-0,279 * \log \left(\mathrm{L}_{\infty}\right)+0,654 * \log$ $(\mathrm{K})+0,4634 * \log (\mathrm{T})$

dimana

$\mathrm{L}_{\infty} \quad$ = panjang asimtotik (di perairan Utara Papua)

$\mathrm{T} \quad=$ rata-rata suhu perairan utara Papua (28ÚC)

Pendugaan mortalitas total (Z), mengunakan metode Beverton \& Holt (1957) dalam Gayanilo et al. (1996) yaitu:
$Z=K \frac{L \infty-\bar{L}}{L-L^{\prime}}$

dimana :

$\overline{\mathrm{L}}=$ panjang rata - rata yang tertangkap

$\mathrm{L}^{\prime}=$ batas terkecil ukuran kelas panjang yang telah tertangkap

Kematian karena penangkapan (F) dihitung dengan mengurangkan kematian alami $(\mathrm{M})$ terhadap kematian to$\operatorname{tal}(Z)$ :

$\mathrm{F}=\mathrm{Z}-\mathrm{M}$

Tingkat eksploitasi (E) dihitung menggunakan persamaan Gulland (1971):

$\mathrm{E}=\mathrm{F} / \mathrm{Z}$ atau $\mathrm{E}=\mathrm{F} /(\mathrm{F}+\mathrm{M}))$

\section{HASIL DAN BAHASAN \\ Hasil}

\section{Struktur Ukuran Ikan Cakalang}

Frekuensi panjang ikan cakalang hasil tangkapan pancing tonda dan pancing ulur di Samudera Pasifik bagian Barat selama 12 bulan menyebar normal dengan modus antara 40-45 cmFL. Panjang ikan terkecil $15 \mathrm{cmFL}$ dan terpanjang $94 \mathrm{cmFL}$ (Gambar 2).

\section{Ukuran Pertama Kali Tertangkap}

Peluang ikan untuk lolos atau tertahan tergantung pada ukuran ikan tersebut. Jika hubungan antara peluang tertahannya ikan oleh alat tangkap dengan panjang tubuh ikan diplotkan ke dalam bentuk grafik, maka akan diperoleh kurva seleksi penangkapan. Kurva ini kemudian digunakan untuk menduga ukuran ikan pertama kali tertangkap (length at first capture/ $L c$ ). Nilai Lc dihitung berdasarkan frekuensi kumulatif dari distribusi panjang ikan menggunakan program FiSAT-II Diperoleh nilai Lc ikan cakalang pada frekuensi kumulatif 50\% sebesar 40,1 cm (Gambar 3.).

\section{Parameter Pertumbuhan}

Dengan merunut data frekuensi panjang cagak ikan cakalang dari bulan ke bulan menggunakan ELEFAN I dalam software FiSAT II diperoleh panjang asimtotik $\left(\mathrm{L}_{\infty}\right)$ $101,85 \mathrm{~cm}$, dan laju pertumbuhan $(\mathrm{K}) 0,41$ per tahun dengan nilai $\mathrm{Rn}=0,198$. 


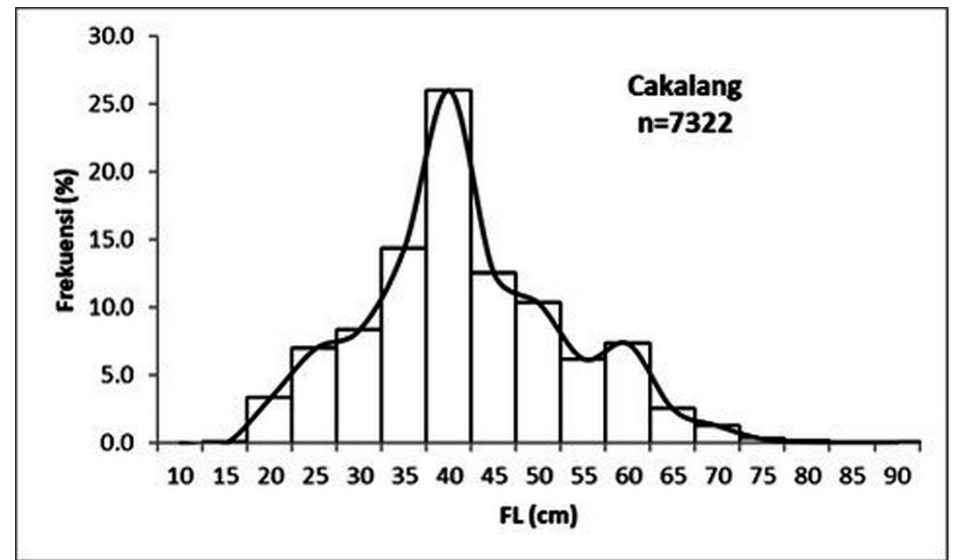

Gambar 2. Distribusi frekuensi panjang ikan cakalang tertangkap di Samudera Pasifik utara Papua, Januari-Desember 2013.

Figure 2. Length frequency distribution of skipjack tuna caught in Pacific Ocean north of Papua, January-December 2013.

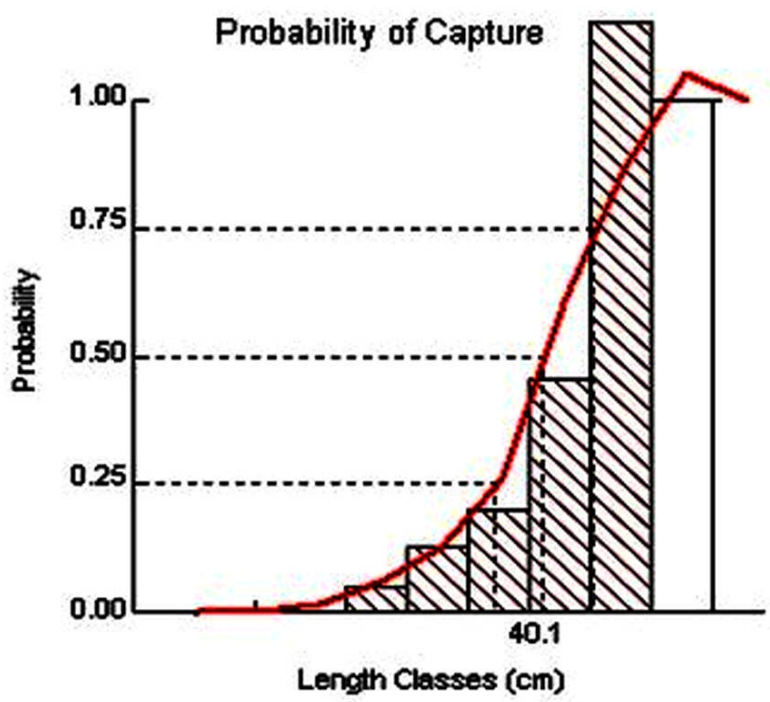

Gambar 3. Ukuran pertama kali tertangkap ikan cakalang tertangkap di Samudera Pasifik utara Papua.

Figure 3. Length at first capture of skipjack tuna caught in Pacific Ocean north of Papua.

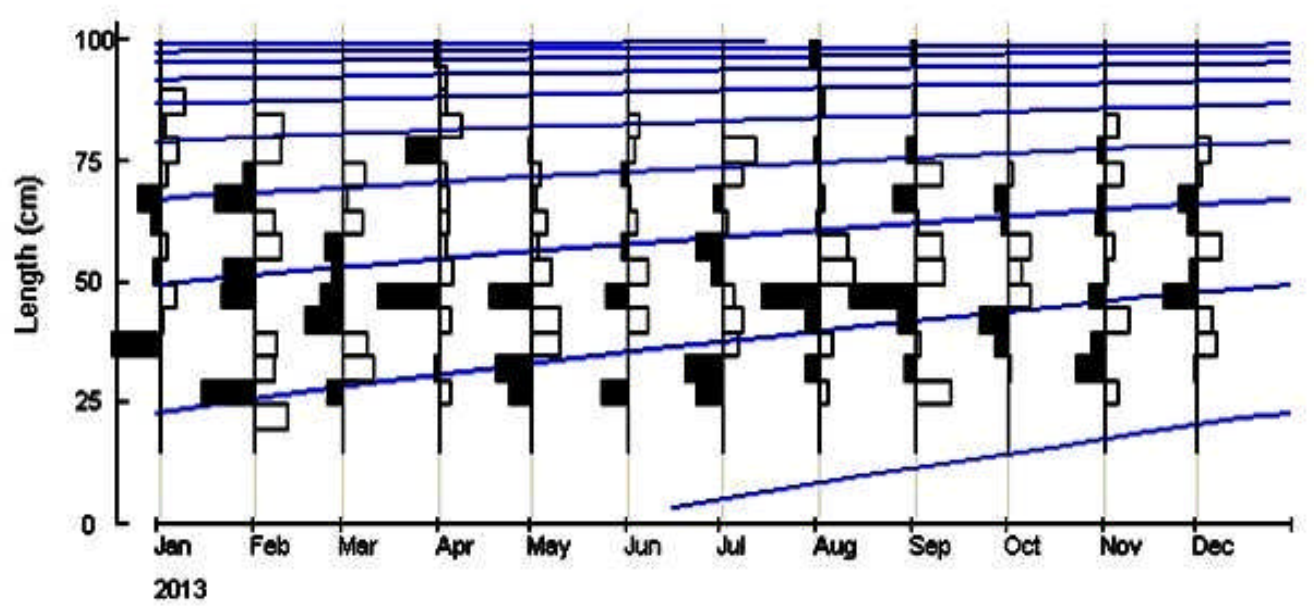

Gambar 4. Penyebaran frekuensi panjang cagak bulanan ikan cakalang yang dirunut dengan dengan metode ELEFAN I.

Figure 4. Monthly fork length distribution of skipjack tuna caught by using ELEFAN I method. 
Dengan menggunakan data panjang asimtotik $\left(\mathrm{L}_{\infty}\right)$, laju pertumbuhan $(\mathrm{K})$ dan nilai $\mathrm{t}_{0}$ diperoleh persamaan pertumbuhan Von Bertalanffy $\mathrm{Lt}=101,85\left(1-\mathrm{e}^{-0.41(t+0.28651)}\right)$. Kurva hubungan antara umur dengan panjang ikan dapat dilihat pada Gambar 5. Dari kurva tersebut dapat diketahui ikan cakalang pada umur 1, 2, 3, 4, dan 5 tahun masing- masing mempunyai ukuran panjang FL sebesar 41,7, 61,9, $75,3,84,2$, dan $90,2 \mathrm{~cm}$. Kecepatan pertumbuhan tertinggi terjadi pada umur 0 sampai 1 tahun yaitu rata-rata $3,47 \mathrm{~cm}$ per bulan, dan umur 1-2 tahun yaitu $1,7 \mathrm{~cm}$ per bulan, panjang infinity ikan cakalang yaitu $101,85 \mathrm{~cm}$ diperkirakan tercapai pada umur ikan sekitar 35 tahun.

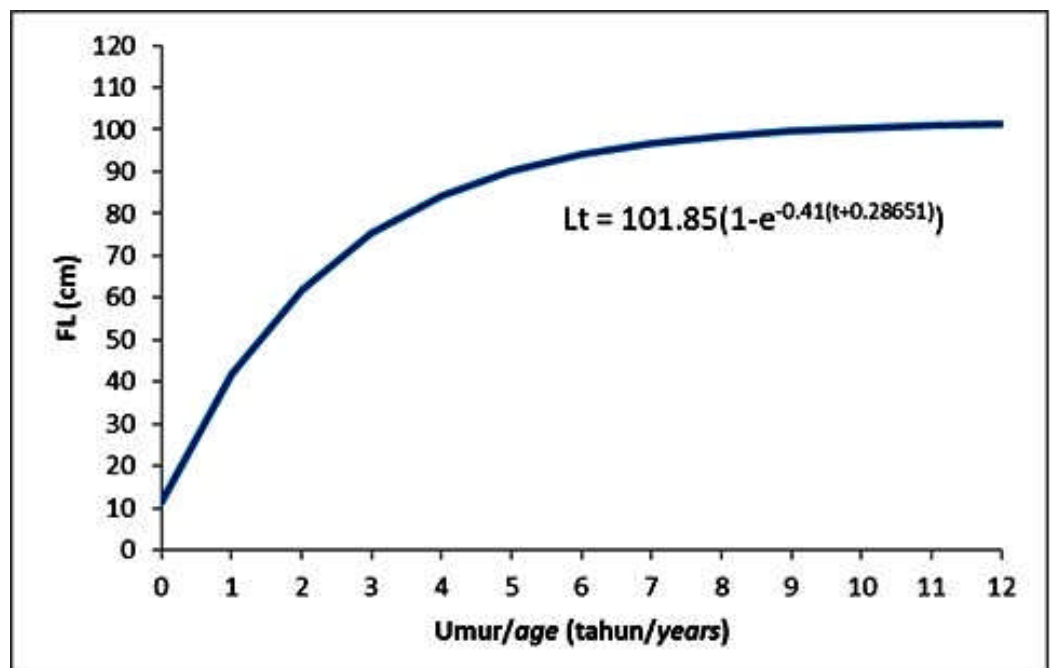

Gambar 5. Kurva pertumbuhan ikan cakalang di Samudera Pasifik utara Papua.

Figure 5. Growth curve of skipjack tuna in the Pacific Ocean north of Papua.

\section{Laju Kematian dan Tingkat Eksploitasi}

Analisis dengan program FISAT II diperoleh laju kematian alami $(M)=0,75$ per tahun. Pauly (1980) menyatakan laju kematian alami untuk ikan-ikan yang bermigrasi seperti ikan cakalang harus dikalikan dengan 0,8. Dengan demikian maka nilai $\mathrm{M}$ disini menjadi 0,6 per tahun. Dengan menggunakan parameter pertumbuha $(\mathrm{K}$, $\left.\mathrm{L}_{\infty}\right)$ yang telah dihitung sebagai bahan masukan untuk membuat kurva hasil tangkapan, diperoleh nilai dugaan Kematian total (Z) sebesar 1,22 per tahun. Kematian akibat penangkapan $(\mathrm{F})$ merupakan kematian total $(\mathrm{Z})$ dikurangi kematian alami (M) yaitu sebesar 0,62 per tahun.

Gambar 6 menunjukkan kurva hasil tangkapan berdasarkan panjang. titik berwarna hitam menggambarkan kelompok ikan cakalang yang telah dieksploitasi, titik berwarna kunung menunjukkan kelompok ikan yang belum sepenuhnya masuk daerah penangkapan. Dengan menggunakan nilai $\mathrm{F}$ dan $\mathrm{Z}$ sebagai masukan, diperoleh estimasi tingkat eksploitasi (exploitation rate, E) ikan cakalang di Samudera Pasifik utara Papua adalah 0,46.

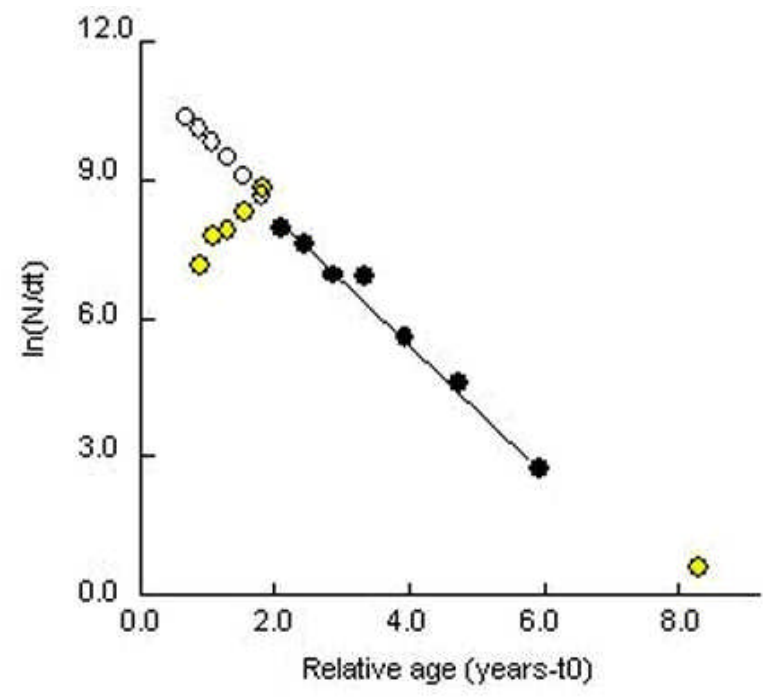

Gambar 6. Kurva hasil tangkapan yang dilinierkan berdasarkan data panjang ikan cakalang, nilai z sebagai slope kurva Figure 6. Length converted catch curve of skipjack tuna, the value of $z$ as slope of curve 


\section{Bahasan}

Dugaan nilai parameter pertumbuhan $\mathrm{L}_{\infty}$ dan $\mathrm{K}$ ikan cakalang tertangkap di perairan Pasifik utara Papua adalah masing-masing sebesar $101,85 \mathrm{~cm}$ dan 0,41 pertahun. Nilai $\mathrm{K}$ ikan cakalang yang lebih kecil dari 0,5 menunjukkan bahwa ikan tersebut mempunyai pertumbuhan yang lambat (Sparre \& Venema, 1999). Nilai ini menunjukkan perbedaan jika dibandingkan dengan nilai $\mathrm{L} \infty$ dan $\mathrm{K}$ yang diduga oleh peneliti lainnya untuk spesies yang sama (Tabel 1.). Perbedaan nilai $\mathrm{L} \infty$ dan $\mathrm{K}$ ini karena adanya perbedaan metode yang digunakan dan habitat perairan yang berbeda.

Tabel 1. Estimasi parameter pertumbuhan ikan cakalang di beberapa area

Table 1. Estimation of growth parameter of skipjack tuna in several area

\begin{tabular}{|c|c|c|c|c|}
\hline Lokasi/location & $\mathbf{L} \infty(\mathbf{c m F L})$ & K/thn/(K/Year $)$ & Method/method & Acuan/reference \\
\hline $\begin{array}{l}\text { Pasifik Tengah \& } \\
\text { Barat }\end{array}$ & 102,2 & 0,55 & Otolith & Uchiyama \& Struhsaker, 198 \\
\hline Pasifik Tengah & 74,8 & 0,515 & Length-freq & Wankowski, 1981 \\
\hline $\begin{array}{l}\text { Pasifik Barat } \\
\text { /Vanuatu }\end{array}$ & 60 & 0,75 & Length-freq & Brouard et al., 1984 \\
\hline Pasifik Timur & 96,3 & 0,515 & Tagging & Bayliff, W.H., 1988 \\
\hline Maldive & 64,3 & 0,55 & Tagging & Adam M.S, 1999 \\
\hline Pasifik Barat /Jepang & 93,6 & 0,43 & Otolith & Tanabe et al., 2003 \\
\hline Atlantik Timur & 97,25 & 0,25 & Tagging & $\begin{array}{l}\text { Hallier \& } \\
\text { Gaertner, } 2006\end{array}$ \\
\hline Atlantik Timur & $89,4-112,3$ & $0,14-0,38$ & Tagging & Gaertner et al., 2008. \\
\hline India & 92 & 0,5 & Length-freq & Koya et al., 2012 \\
\hline Papua Nugini & 150 & 0,3 & Length-freq & $\begin{array}{l}\text { Kumasi et al. } 2012 \\
\text { Garbin T. \& }\end{array}$ \\
\hline Atlantik Tenggara & 66,9 & 0,24 & Length-freq & J.P. Castello. 2014 \\
\hline Pasifik barat/Papua & 101,85 & 0,41 & Length-freq & Penelitian ini/ this study \\
\hline
\end{tabular}

Nilai dugaan kematian total $(Z)$ dari penelitian ini sebesar 1,22 per tahun menunjukkan perbedaan dari nilai dugaan $Z$ yang diperoleh peneliti sebelumnya pada spesies yang sama di Samudera Pasifik, yaitu 1,38-3,0 pertahun (Tandog-Edralin et al., 1987) dan 1,41 pertahun (Koya, 2012).Kematian alami (M) yang diduga dengan menggunakan formula empiris Pauly pada penelitian ini sebesar 0,6 pertahun memperlihatkan perbedaan jika dibandingkan dari hasil peneliti lainnya pada spesies yang sama, yaitu 0,74-0,9 pertahun (Tandog-Edralin et al., 1987) dan 0,557 pertahun (Koya, 2012).

Menurut Atmaja \& Nugroho (2004) kematian ikan akibat penangkapan berbanding lurus dengan upaya penangkapan dan kemampuan tangkap. Hal ini berarti kenaikan kematian akibat penangkapan akan diikuti dengan kenaikan upaya penangkapan. Gulland (1971) menduga bahwa dalam stok yang dieksploitasi optimal maka laju mortalitas penangkapan (F) sama dengan laju mortalitas alami (M) atau laju eksploitasi (E) sama dengan 0,5. Tingkat eksploitasi ikan cakalang di Samudera Pasifik utara Papua adalah 0.46. Hal ini menunjukkan pemanfaatan ikan cakalang di Samudera Pasifik utara Papua sudah optimal, artinya pemanfaatan harus sudah dikelola dengan hatihati dan penambahan armada penangkapan tidak diperlukan lagi.
Nilai Lc ikan cakalang yang tertangkap di Samudera Pasifik utara Papua dengan alat tangkap pancing ulur dan pancing tonda sebesar 40,1 cmFL. Ikan cakalang yang tertangkap menunjukkan ikan yang sedang memijah. menurut Matsumoto et al. (1984), ukuran pertama kali matang gonad ikan cakalang di Perairan Jepang adalah 40$45 \mathrm{~cm}$, sedangkan Ashida et al. (2009) menyatakan ukuran pertama kali matang gonad di Samudera Pasifik bagian tengah dan barat sebesar $40 \mathrm{~cm}$. Menurut Jamal et al., (2011) ukuran pertama kali matang gonad ikan ini di perairan Teluk Bone sebesar 46,5 cm. Dari informasi ini maka dapat disimpulkan bahwa ikan cakalang yang tertangkap pancing tonda dan pancing ulur sebagian besar dalam fase mendekati memijah.

\section{KESIMPULAN}

Ukuran ikan cakalang (Katsuwonus pelamis) hasil tangkapan pancing tonda dan pancing ulur di Samudera Pasifik utara Papua antara 15 - $94 \mathrm{~cm}$, dengan modus 40-45 cmFL. Laju pertumbuhan $(\mathrm{K})$ sebesar $0.41 /$ tahun dan panjang asimtotik 101,85 cm. Laju kematian alami (M) sebesar 0,6 per tahun dan kematian penangkapan $(\mathrm{F})$ sebesar 0,62 per tahun, sehingga diperoleh nilai kematian total (Z) 1,22. Tingkat eksploitasi ikan cakalang mendekati 
full exploited $(\mathrm{E}=0.46)$. Tingkat eksploitasi disarankan tetap dipertahankan dan tidak perlu ada penambahan upaya penangkapan untuk menjaga kelestrian sumberdaya ikan cakalang

\section{PERSANTUNAN}

Makalah ini merupakan kontribusi dari Kegiatan "Penelitian Aspek Biologi, Tingkat Pemanfaatan dan Optimasi Pemanfaatan Sumberdaya Ikan Pelagis Besar di WPP 572, WPP 573 dan WPP 7171 Untuk Mendukung Industrialisasi Perikanan”. Balai Penelitian Perikanan Laut, Tahun 2013. Ucapan terima kasih juga disampaikan kepada enumerator di ketiga lokasi penelitian atas bantuannya dalam pengumpulan data.

\section{DAFTAR PUSTAKA}

Adam, M.S. (1999). Population dynamics and assessment of Skipjack tuna (Katsuwonus pelamis) in the Maldives. PhD thesis. Imperial College of Science, Technology and Medicine, University of London.

Anonimus. (2014). Buku Tahunan Statistik Perikanan Tangkap Tahun 2013 (p. 63). Dinas Kelautan dan Perikanan, Pemerintah Provinsi Papua.

Ashida, H, Tanabe, T., \& Suzuki, N. (2009). Recent progress on reproductive biology of skipjack tuna in the tropical region of the Western and Central Pacific Ocean Scientific Committee Fifth Regular Session. (p 16). Port Vila, Vanuatu.

Atmaja, S.B., \& Nugroho, D. (2004). Karakteristik parameter populasi ikan siro (Amblygaster sirm) dan model terapan Beverton dan Holt di Laut Natuna dan sekitarnya. J Lit Perik Ind. 10 (4), 9-15.

Bayliû, W.H. (1988). Growth of skipjack Katsuwonus pelamis and yellowûn tuna Thunnus albacares, in the Eastern Paciûc Ocean, as estimated from tagging data. Inter-Am. Trop. Tuna Comm. Bull. 19, 311-358.

Brouard, F., Grandperrin, R,. \& Cillaurren, E. (1984). Croissance des jeunes thons jaunes (Thunnus albacares) et des bonites (Katsuwonus pelamis) dans le Paciûque tropical occidental. (p10). ORSTOM de Port-Vila, Notes Doc Océanogr.

Gayanilo, F.C.Jr, Sparre, P., \& Pauly, D. (1996). FAOICLARM Stock Assessment Tools (FiSAT) user's Guide (p. 126) FAO Computerised Information Series (Fisheries) No. 8 FAO. Rome.
Garbin, T \& Castello, J.P. (2014). Changes in population structure and growth of skipjack tuna, Katsuwonus pelamis during 30 years of exploitation in the southwestern Atlantic. Lat Am J Aquat Res. 42(3), 534546.

Gaertner, D, Molina, A.D, Ariz, J, Pianet, R., \& Hallier, J.P. (2008). Variability of the growth parameters of the skipjack tuna (Katsuwonus pelamis) among areas in the eastern Atlantic: analysis from tagging data within a meta-analysis approach. Aquat Living Resour. 21, 349-3562008.

Gulland, JA. (1971). Fish Resources of the Ocean Fishing New Books, London. 255 p.

Hallier, JP \& Gaertner, D. (2006). Estimated growth rate of the Skipjack tuna (Katsuwonus pelamis) tagging survey conducted in the Senegalese area (1996-1999) within a meta-analysis framework Col Vol Sci Pap ICCAT. 59(2), 411-420 2006.

Jamal M, Sondita, M.F.A, Haluan, J. \& Wiryawan, B. (2011). Pemanfaatan data biologi ikan cakalang (Katsuwonus pelamis) dalam rangka pengelolaan perikanan bertanggung jawab di perairan Teluk Bone Jurnal Natur Indonesia. 14(1)11, 107-113.

Koya, K.P.S., Joshi, K.K., Abdussamad, E.M., Rohit, P, Sivadas, M, Kuriakose, S, Ghosh, S,Koya, M, Dhokia, H.K., Prakasan, D, Koya,V.A.K.. \& Sebastine, M. (2012). Fishery, biology and stock structure of skipjack tuna, Katsuwonus pelamis (Linnaeus, 1758) exploited from Indian waters. Indian. J. Fish. 59(2), 39-47, 2012.

Kumasi, B., Usu, T., Baje, L., \& Kumoru, L. (2012). Decomposition of tuna length frequency data from port sampling in Papua New Guinea Scientific Committee Eighth Regular Session, WCPFC-SC82012 Busan, Republic of Korea.

Matsumoto, W.M., Skillman, R.A., \& Dizon, A.E. (1984). Synopsis of Biological Data on Skipjack Tuna, Katsuwonus pelamis (p. 92). NOAA Tech Rep NMFS Circ (451).

Pauly, D. (1980). On the inter-relationships between natural mortality, growth performanceand mean environmental temperature in 175 fish stock Journal du Conseil International pour I' Exploration de la Mer. 39(3), 175-192.

Pauly, D. (1983). Some Simple Methods in Tropical Fish Stock Assessment (p. 80) FAO. 
Pauly, D \& David, N. (1981). ELEFAN-I a basic program for the objective extraction of growth parameters from Length frequency data Meeresforschung/Rep Mar Res. 28(4), 205-211.

Sparre, P \& Venema, S.C. (1999). Introduksi Pengkajian Stok Ikan Tropis. (p. 438). Buku I: Manual FAODANIDA Puslitbang Perikanan-Departemen Pertanian RI.p

Siriraksophon, S. (2011). Summary on the status of tuna fisheries in the Western Central Pacific Ocean Report of the Special Meeting on Improvement of Tuna Information and Data Collection in Southeast Asia (pp. 1-27) Southeast Asian Fisheries Development Center (SEAFDEC) Songkhla, Thailand.

Tanabe, T., Kayama, S., \& Ogura, M. (2003). An outline of the growth study on skipjack tuna (Katsuwonus pelamis) in the Western Paciûc Doc IOTC WPTT-0317.

Tandog-Edralin, D.D., Cortez-Zaragoza, E..C, Dalzell, P., \& Pauly, D. (1987). Some biology and aspects of the population dynamics of Skipjack (Katsuwonus pelamis) in Philippine waters FAO/IPTP Meeting of Tuna Research Groups in the Southeast Asian Region, Manila, 25-28 August 1987.

Uchiyama, J.H., \& Struhsaker, P. (1981). Age and growth of skipjack tuna Katsuwonus pelamis, and yellowûn tuna, Thunnus albacares, as indicated by daily growth increments of sagittae. Fish Bull. 79, 151-162.

Wankowski, J.W.J. (1981). Estimated growth of surface schooling skipjack tuna, Katsuwonus pelamis, and yellowûn tuna, Thunnus albacares, from the Papua New Guinea Region. Fish Bull. 79, 517-532. 
Appendix 1. Length frequency distribution of skipjack tuna caught by hand line and troll line in thePacific Ocean north of Papua waters

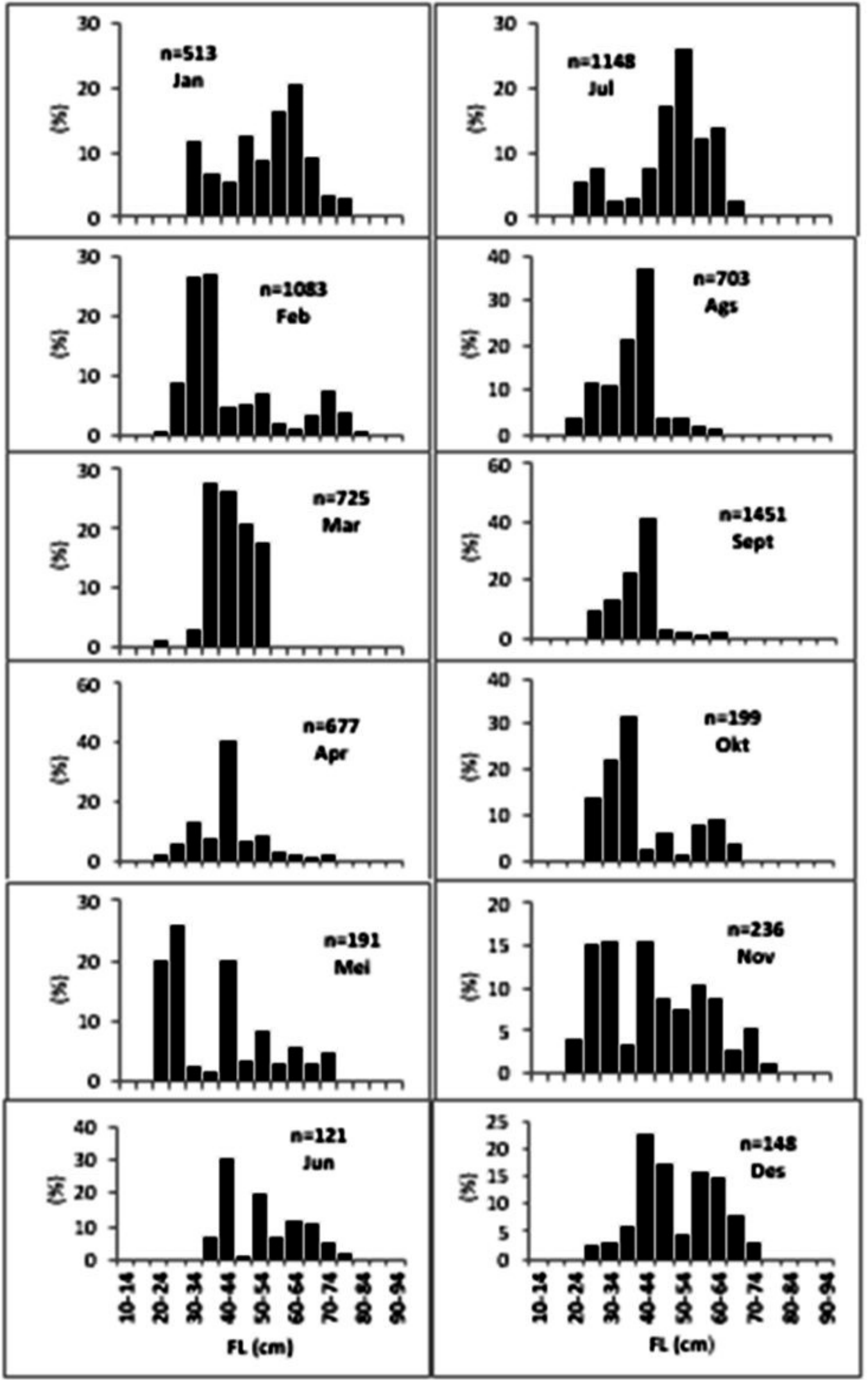

